\title{
PERBANDINGAN ASAM ASETAT DENGAN ASAM FORMIAT SEBAGAI BAHAN PENGGUMPAL LATEKS
}

\section{COMPARISON OF ACETIC ACID WITH AS FORMIIC ACID LATEX PUMP MATERIAL}

\author{
Rudi Munzirwan Siregar'1, Putri Anggita Widodo² \\ ${ }^{1,2}$ Program Studi Kimia, Fakultas FMIPA Universitas Negeri Medan Medan, Indonesia \\ *Email: rudimunzirwam4875@gmail.com
}

Diterima: 29 September 2021. Disetujui: 15 November 2021. Dipublikasikan: 25 Desember 2021

\begin{abstract}
Abstrak: Indonesia merupakan salah satu penghasil karet terbesar. Hampir seluruh lateks kebun untuk produksi karet harus digumpalkan sebelum proses lanjut. Telah dilakukan penelitian tentang perbandingan asam asetat dengan asam formiat sebagai bahan penggumpal lateks. Pada penelitian ini bertujuan untuk membandingkan asam asetat dengan asam formiat sebagai bahan penggumpal lateks . Kedalam lateks ditambahkan arang tempurung kelapa (ukuran partikel 80 mesh) dengan berat 42 gram kemudian lateks digumpalkan dengan asam asetat dan asam formiat dengan $\mathrm{pH}$ 4,7. Sebagai penelitian mutu karet dilakukan dengan mengukur plastisitas awal, plastisitas retensi indeks dan viskositas mooney karet. Kesimpulannya, lateks yang digumpalkan dengan asam asetat menghasilkan karet yang lebih baik dibandingkan dengan lateks yang digumpalkan dengan asam formiat.
\end{abstract}

Kata Kunci: Lateks, Asam Asetat, Asam Formiat, Arang Tempurung Kelapa

Abstract: Indonesia is one of the largest rubber producers. Almost all garden latex for rubber production must be coagulated before further processing. Research has been carried out on the comparison of acetic acid with formic acid as a latex coagulation agent. This study aims to compare acetic acid with formic acid as a latex coagulation agent. Coconut shell charcoal (particle size $80 \mathrm{mesh}$ ) was added to the latex with a weight of 42 grams then the latex was coagulated with acetic acid and formic acid with a $\mathrm{pH}$ of 4.7. As a rubber quality research was carried out by measuring the initial plasticity, plasticity retention index and mooney viscosity of rubber. In conclusion, latex coagulated with acetic acid produced better rubber than latex coagulated with formic acid.

Keywords : Latex, Acetic Acid, Formic Acid, Coconut Shell Charcoal

\section{PENDAHULUAN}

Penanganan hasil panen tanaman karet berupa lateks prlu diupayakan untuk meningkatkan mutu bahan oleh karet berdaya saing tinggi di pasar nasional maupun internasional. Secara ekonomis, tidak terjangkaunya bahan penggumpal anjuran di tingkat petani menjadi pemicu penggunaan bahan penggumpal seperti TSP dan sebagainya [1].

Pada proses pengolahan karet terdapat tahapan penggumpalan lateks. Penggumpalan lateks dapat terjadi karena rusaknya kemantapan sistem koloid lateks. Kerusakan ini dapat terjadi dengan jalan penetralan muatan protein dengan penambahan asam sehingga muatan negatif dan muatan positif lateks setimbang ( $\mathrm{pH} 4,7)$. Bahan kimia yang biasa digunakan dalam penggumpalan lateks adalah asam formiat. Asam ini dapat digunakan untuk menghambat terjadinya reaksi pengerasan pada karet selama penyimpanan [2].

Koagulasi merupakan peristiwa fase sol menjadi gel dengan pertolongan bahan penggumpalan yang lazimnya digunakan koagulan. Bahan penggumpal atau koagulan yang umum digunakan perusahaan perkebunan adalah asam format. Dengan alasan harga yang mahal dan ketersediaan yang langka dari asam format sebagai bahan penggumpal, sehingga masih banyak para petani karet yang tidak menggunakan asam formiat sebagai koagulan. Mereka lebih cenderung menggunakan asam sulfat, tawas, TSP, dan lain-lain dengan pertimbangan harganya yang murah [3].

Menurut Prabaya (2011) penggunaan koagulan jenis asam sulfat dan tawas dapat merusak nilai plastisitas dari karet sedangkan TSP plastisitas tercapai jika campuran TSP dan lateks didekantasi terlebih dahulu, disamping itu juga dapat meningkatkan jumlah pengotor.

Dilain pihak asam asetat dapat digunakan sebagai bahan penggumpal lateks. Asam ini juga dapat memperbaiki kekerasan karet [4]. Penggunaan asam sangat berperan dalam menghindari terjadinya degradasi protein pada saat proses penggumpalan karet dan dapat mencegah timbulnya bau yang tidak sedap pada karet. Akan tetapi, disamping untuk mendapatkan kualitas yang baik koagulan ini juga dapat memberikan dampak negatif terhadap 
lingkungan sekitar sekitar serta memberi resiko terhadap para pekerja terutama pada pernapasan dan iritasi kulit.

Jadi, dengan mempertimbangkan pemahaman dan keterampilan para petani lateks yang masih minim tentang proses penggumpalan lateks di kebun, sehingga berdampak pada mutu bahan olahan karet yang dihasilkan, serta mempertimbangkan koagulan lateks yang mempunyai efek negatif bagi kesehatan dan lingkungan. [5]

Dengan demikian lateks yang digumpalkan dengan asam asetat dan asam formiat diharapkan dapat memperbesar volume dari karet dan memperbaiki kekerasan karetnya sehingga mutu karetnya lebih baik [6]. Berdasarkan hal tersebut, penulis ingin membandingkan asam asetat dengan asam formiat sebagai bahan penggumpal lateks

\section{METODE PENELITIAN}

\section{Alat dan Bahan}

Alat yang digunakan dalam penelitian ini adalah Blanding mill, Lab mill, Wallace punch, Wallace plastimeter, Mooney Viscosimeter, Creper, Neraca analitis, Termometer, Stopwatch, Pembakar listrik, Oven, Desikator, dan Muffle Furnace. Bahan yang digunakan adalah Lateks, Asam asetat, Arang yang diayak dengan ukuran 80 mesh, dan kertas lakmus indikator.

\section{Pembuatan arang dari tempurung kelaoa}

Sebanyak 2 buah tempurung kelapa dibersihkan, dijemur di bawah sinar matahari, dan dipotong menjadi ukuran yang lebih kecil lalu dimasukkan ke dalam cawan porselin dan ditutup dengan aluminium foil. Selanjutnya dimasukkan ke dalam tanur pada suhu $500{ }^{0} \mathrm{C}$ selama 4 jam, lalu didinginkan dalam desikator dan dicuci dengan akuades. Arang yang terbentuk diovenkan pada suhu $100-105^{\circ} \mathrm{C}$, lalu didinginkan dalam desikator dan diayak dengan ayakan 80 mesh

\section{Asam asetat sebagai penggumpal lateks dengan bahan pengisi arang \\ Disediakan lateks sebanyak 4 liter. Lateks}

kebun disaring dengan saringan 40 mesh untuk menghilangkan kotoran-kotoran yang terikut pada waktu penyadapan. Masing- masing 1 liter lateks dimasukkan kedalam mangkuk penggumpal, untuk mangkuk 1; 1 liter lateks ditambahkan arang yang ukuran partikelnya 80 mesh sebanyak 42 gram, lalu ditambahkan sedikit demi sedikit asam asetat sampai $\mathrm{pH} 4,7$; volume asam asetat saat $\mathrm{pH} 4,7$ adalah 20 ml. Perlakuan diatas diulangi dua kali perlakuan. Masing-masing koagulum karet yang terbentuk ditambahkan air secukupnya untuk menutupi permukaan koagulum tersebut, kemudian didiamkan selama satu malam. Selanjutnya masing-masing koagulum digiling dengan alat creper sebanyak sembilan kali gilingan dan diovenkan pada suhu 110 ${ }^{0} \mathrm{C}$ selama tiga setengah jam sehingga menghasilkan karet yang kering. Setelah itu masing-masing koagulum karet yang sudah kering digiling dengan alat lab mill sebanyak enam kali. Karet kering yang dihasilkan diuji mutu karetnya sesuai dengan ketentuan standard Indonesian rubber .

\section{Penetapan Nilai Plastisitas Awal Dan Plastisitas} Retensi Indeks (Kartowardoyo, 2015)

Ditimbang sekitar 25 gram karet yang sudah dikeringkan, lalu digiling dengan gilingan laboratorium sebanyak tiga kali dengan ketebalan antara 1,6- 1,8 mm. Lembaran karet tersebut dilipat dua, ditekan perlahan-lahan dengan telapak tangan sehingga mempunyai ketebalan 3,3-3,6 mm. Kemudian lembaran karet tersebut dipotong dengan alat Wallace punch sebanyak enam buah potongan uji dengan diameter $13 \mathrm{~mm}$. Untuk pengukuran plastisitas awal diambil potongan uji (1), sedangkan potongan uji (2) untuk pengukuran plastisitas setelah pengusangan. Potongan uji harus mempunyai ketebalan antara 3,2- 3,6 mm (ketelitian 0,01 mm) dengan garis tengah $1,3 \mathrm{~mm}$. Diletakkan potongan uji (2) untuk pengukuran plastisitas setelah pengusangan diatas baki dan dimasukkan kedalam oven pada suhu $140^{\circ} \mathrm{C}$ selama 30 menit. Lalu dikeluarkan kemudian didinginkan sampai suhu kamar.

Sementara potongan uji (1) sebanyak tiga buah diletakkan satu persatu diantara dua lembar kertas sigaret TST yang berukuran $35 \mathrm{~mm}$ x $45 \mathrm{~mm}$ selanjutnya diletakkan di atas piringan plastimeter lalu piringan plastimeter tersebut ditutup. Setelah ketukan pertama piringan bawah plastimeter akan bergerak ke atas selama 15 detik dan menekan piringan atas. Dilanjutkan sampai ketukan kedua berakhir yang ditandai dengan angka jarum mikrometer berhenti bergerak pada nilai plastisitas karet. Sedangkan potongan uji (2) setelah pengusangan tadi diukur dengan cara yang sama. Tiga potongan uji dari setiap contoh diambil angka rata- ratanya dan dibulatkan. Nilai plastisitas retensi indeks (PRI) dinyatakan dalam persen dengan rumus sebagai berikut:

\footnotetext{
PRI $=\frac{P a \times 100 \%}{P_{0}}$

$\mathrm{Pa}=$ Plastisitas Setelah pengusangan

$\mathrm{Po}=$ Plastisitas Sebelum Pengusangan
} 


\section{Pengujian Viskositas Money (Subramaniam, 2016)}

Alat viskosimeter terlebih dahulu dipanaskan selama satu jam. Masing-masing lembaran contoh karet diambil 2 buah potongan uji dengan menggunakan alat Wallace punch sehingga ukuran diameternya sama dengan ukuran diameter rotor. Ditusukkan rotor ke contoh karet pertama yang telah diberi lubang dengan gunting. Contoh kedua diletakkan tepat di atas rotor lalu dimasukkan bersama ke stator bawah. Ditutup stator atas dan setelah tertutup stopwatch dihidupkan. Setelah tepat satu menit, dijalankan rotor. Nilai viskositas dibaca dengan alat penunjuk. Angka yang ditunjukkan jarum mikrometer setelah menit keempat adalah nilai viskositas karet.

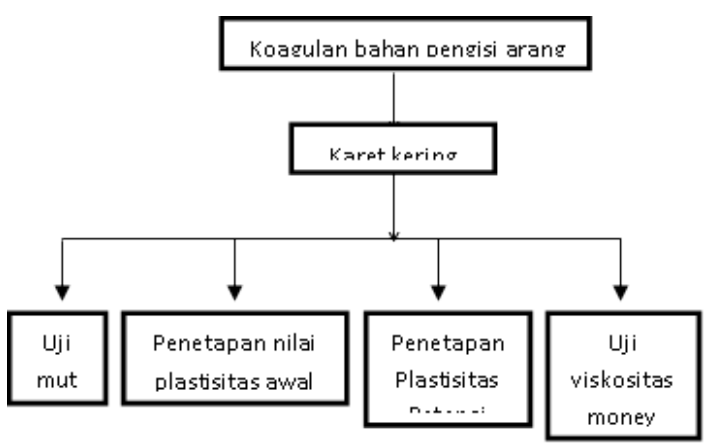

Skema Penelitian

\section{HASIL DAN PEMBAHASAN.}

Plastisitas awal adalah plastisitas karet mentah yang langsung diuji tanpa perlakuan khusus sebelumnya, yang ditentukan dengan alat Wallace plastimeter. Nilai plastisitas awal (Po) merupakan parameter dasar untuk menentukan mutu karet lembaran. Semakin tinggi nilai plastisitas awal maka semakin kecil energi yang diperlukan dalam proses pembuatan komponen karet [7]. Karet yang mempunyai plastisitas awal tinggi mempunyai rantai molekul yang tahan terhadap oksidasi, sedangkan yang mempunyai plastisitas awal rendah mudah teroksidasi menjadi karet lunak [8]. Hasil plastisitas awal (Po) karet dengan penggumpal asam asetat dapat dilihat pada Tabel 1

Tabel 1. Hasil plastisitas awal (Po) karet dengan penggumpal asam asetat dan asam formiat.

\begin{tabular}{ccccccc}
\hline \multirow{2}{*}{ Perlakuan } & \multicolumn{3}{c}{$\begin{array}{c}\text { Plastisitas awal } \\
\text { asam formiat } \\
(\%)\end{array}$} & \multicolumn{3}{c}{$\begin{array}{c}\text { Plastisitas awal } \\
\text { asam asetat }(\%)\end{array}$} \\
\cline { 2 - 7 } & 1 & 2 & $\begin{array}{c}\text { Rata- } \\
\text { rata }\end{array}$ & 1 & 2 & $\begin{array}{c}\text { Rata- } \\
\text { rata }\end{array}$ \\
\hline $\begin{array}{c}\text { 42 gram } \\
\text { arang }\end{array}$ & 46 & 45 & 45.5 & 49 & 48 & 48.5 \\
\hline
\end{tabular}

Tabel 1 emenunjukkan bahwa lateks yang digumpalkan dengan asam asetat menghasilkan nilai plastisitas awal yang lebih tinggi bila dibandingkan dengan lateks yang digumpalkan dengan asam formiat yaitu dengan rata-rata 48,5\% dibandingkan dengan rata-rata nilai plastisitas asam formiat sebesar $45,5 \%$. Hal ini berarti dengan penambahan asam asetat menyebabkan logam dan zat-zat pengotor yang terdapat pada lateks berkurang pada waktu penggumpalan, sehingga nilai plastisitas awal karet yang dihasilkan tinggi, dan mutunya lebih baik [9].

\section{Plastisitas Retensi Indeks (PRI)}

Nilai plastisitas Retensi indeks adalah suatu ukuran ketahanan karet terhadap pengusangan atau oksidasi pada suhu tinggi. Rantai molekul karet alam yang tahan terhadap oksidasi memilliki plastisitas awal yang tinggi dan polanya sama seperti PRI. Tinggi rendahnya nilai PRI dipengaruhi oleh jenis bahan baku yang digunakan dan proses pengolahan karet. Semakin tinggi nilai PRI berarti ketahanan karet mentah terhadap degradasi akan semakin tinggi, yang berarti karet semakin keras. Faktor utama yang berpengaruh terhadap nilai plastisitas retensi indeks adalah zat peroksidan (logam-logam yang berasal dari lateks) dan zat- zat anti oksidan (protein, dan senyawa lain yang terabsorpsi pada karet) [10]. Hasil plastisitas retensi indeks (PRI) karet dengan penggumpal asam asetat dan asam formiat dapat dilihat pada Tabel 2.

Tabel 2. Plastisitas Retensi Indeks Karet dengan Penggumpal Asam Asetat dan Asam formiat

\begin{tabular}{lllllll}
\hline Perlakuan & \multicolumn{2}{l}{$\begin{array}{l}\text { Nilai Plastisitas } \\
\text { retensi indeks(PRI) } \\
\text { asam formiat (\%) }\end{array}$} & \multicolumn{2}{l}{$\begin{array}{l}\text { Nilai Plastisitas } \\
\text { Retensi indeks } \\
\text { asam }\end{array}$} \\
\cline { 2 - 7 } & 1 & 2 & $\begin{array}{l}\text { Rata- } \\
\text { rata }\end{array}$ & 1 & 2 & $\begin{array}{l}\text { Rata- } \\
\text { rata }\end{array}$ \\
\hline $\begin{array}{l}\mathbf{4 2} \text { gram } \\
\text { arang }\end{array}$ & 81 & 80 & 80.5 & 82 & 84 & 83 \\
\hline
\end{tabular}

Dari tabel 2 diatas menunjukkan bahwa lateks yang digumpalkan dengan asam asetat menghasilkan nilai plastisitas retensi indeks yang lebih tinggi bila dibandingkan dengan lateks yang digumpalkan dengan asam formiat. Hal ini berarti lateks yang digumpalkan dengan asam asetat mempunyai ketahanan terhadap pegusangan atau oksidasi pada suhu tinggi yang lebih baik bila dibandingkan dengan lateks yang digumpalkan dengan asam formiat sehingga mutu karet yang dihasilkan lebih baik [11].

\section{Viskositas Mooney}

Viskositas karet mentah dinyatakan sebagai viskositas mooney, yang menunjukkan panjangnya 
rantai molekul, berat molekul, dan derajat pengikatan silang rantai molekulnya. Jika nilai viskositas tinggi berarti karet keras sehingga mutu karet yang dihasilkan tinggi sebaliknya jika nilai viskositas rendah berarti karet lunak sehingga mutu karet yang dihasilkan turun [12]. Hasil Viskositas Mooney dengan penggumpal asam asetat dan asam formiat dapat dilihat pada Tabel 3 .

Tabel 3. Viskositas Mooney Karet dengan penggumpal Asam Aseat dan Asam Formiat

\begin{tabular}{|c|c|c|c|c|c|c|}
\hline \multirow{2}{*}{$\begin{array}{l}\text { Perla } \\
\text { kuan }\end{array}$} & \multicolumn{3}{|c|}{$\begin{array}{l}\text { Nilai viskositas } \\
\text { mooney asam } \\
\text { asetat }(\%)\end{array}$} & \multicolumn{3}{|c|}{$\begin{array}{c}\text { Nilai viskositas } \\
\text { mooney asam } \\
\text { formiat }(\%)\end{array}$} \\
\hline & 1 & 2 & $\begin{array}{c}\text { Rata- } \\
\text { rata }\end{array}$ & 1 & 2 & $\begin{array}{l}\text { Rata- } \\
\text { rata }\end{array}$ \\
\hline $\begin{array}{c}42 \\
\text { gram } \\
\text { arang }\end{array}$ & 77 & 78 & 77,5 & 76 & 76 & 76 \\
\hline
\end{tabular}

Tabel 3 menunjukkan bahwa lateks yang digumpalkan dengan asam asetat menghasilkan nilai viskositas mooney yang lebih tinggi bila dibandingkan dengan lateks yang digumpalkan dengan asam formiat, karena dengan penambahan penggumpal asam asetat, maka kandungan senyawa bukan karet yang berfungsi sebagai katalis pembentuk ikatan silang terlarut dalam fase serum, sehingga karet yang dihasilkan keras dan mempunyai ketahanan yang tinggi terhadap gesekan bila dibandingkan dengan lateks yang digumpalkan dengan asam Formiat (Lim, 1989).

\section{KESIMPULAN}

Dari hasil penelitian yang telah dilakukan dapat disimpulkan bahwa lateks yang digumpalkan dengan asam asetat menghasilkan mutu karet yang lebih baik dibandingkan dengan lateks yang digumpalkan dengan asam formiat, karena nilai platisitas awal

Berdasarkan hasil penelitian dan analisa yang dilakukan disarankan kepada peneliti selanjutnya untuk meneliti lempung (kaolin) sebagai bahan pengisi lateks yang digumpalkan dengan asam asetat lalu hasilnya dibandingkan dengan bahan pengisi arang sehingga kita akan mengetahui mana yang lebih baik digunakan sebagai bahan pengisi supaya mutu karet yang dihasilkan lebih baik.

\section{DAFTAR PUSTAKA}

[1] Rachmawan, A., Wijaya, A., (2017), Asap Cair Sebagai Penggumpal Lateks, 1(1), 8-13

[2] Budiman S. 2017. Rencana Perbaikan Pengolahan Karet Rakyat Dalam Perbaikan Mutu Ekspor, Kelompok teknologi pengolahan hasil pusat penelitian perkebunan sungai putih

[3] Purnamasari, I., Prastanto, H., (2014), Pengaruh Penambahan Ekstrak Belimbing Wuluh Sebagai Bahan Penggumpal Terhadap Kualitas Karet SIR 20, KINETIKA, 5 (1), 3338

[4] Anna. H. M. 2019. Pemanfaatan Arang Cangkang Kemiri dan Arang Aktif Cangkang Kemiri Untuk Menyerap Logam Krom dengan spektrofotometri Serapan Atom". Skripsi Jurusan Kimia, FMIPA USU.

[5] Nindi, V., Naswir, M., Suryadri, H., (2021), Aplikasi Asap Cair Batubara Sebagai koagulan lateks Serta Pengaruhnya Terhadap Struktur dan Kualitas Lateks, Jurnal Engineering, 3(1), 36-44

[6] Haradi B. 2017. Usaha Perbaikan Mutu Bahan Olah Karet. Direktorat Jendral Perkebunan

[7] Poppy, M., Assa, A., Prasetya, H.A., (2020), Karakteristik Karet Lembaran Dengan Bahan Pengisi Arang Aktif Bambu, Jurnal Industri Perkebunan, 15(1), 1-9.

[8] Hanggokusumo S. 2018. Permintaan konsumen mengenai spesifikasi SIR, warta perkaretan volume

[9] Nelteresia. 2018. Pemanfaatan destilat limbah cair kakao sebagai penggumpal lateks, Skripsi jurusan kimia universitas sumatera utara.

[10] Soewarti. 2016. Pengaruh arang dan $\mathrm{PH}$ terhadap lateks kebun dengan sifat karet yang diperoleh, Menara perkebunan, volume 3

[11] Kartowardoyo S. 2015. Penggunaan wallace Plastimeter untuk penentuan karakter pematangan karet alam, UGM Yogyakarta

[12] Hidayoko, G., Wulandra, O., (2014), Pengaruh Penggunaan Jenis Bahan Penggumpal Lateks Terhadap Mutu SIR 20, Agritepa, vol 1(1), 219-130 